\title{
ORGANIC FOOD IN THE HOSPITALITY INDUSTRY - SUPPLY AND DEMAND
}

\author{
Jelena Dević Blanuša ${ }^{1 *}$, Bojana Kalenjuk1, Snježana Gagić \\ Received: July 11, 2017 | Accepted: October 17, 2017
}

\begin{abstract}
The quality of life with a focus on nutrition increasingly occupies modern consumers as well as the hospitality-tourist market. The goal of proper nutrition and health-safe food put organic food at the forefront, conditioning contemporary hospitality workers to put organic foods on their offer, whether in the form of a bio-corner or a menu. Since the number of satisfied tourists is important for the development of the region, the paper examines the supply of organic food in the hospitality facilities of Novi Sad, as a regional centre where agriculture represents an important activity. The task of the paper is to investigate the requirements of tourists for dishes made of organic foodstuffs, as well as the possibility of responding to them within the hospitality facilities. The aim of the paper is to examine the level of the organic food supply in the hospitality industry and to give guides for its improvement.
\end{abstract}

Keywords: organic food, organic production, supply, demand, hospitality industry.

\section{INTRODUCTION}

The way and the pace of life of today's people today have the significantly influenced diet. Due to no time, at least one meal is realized daily outside the home, which goes in favour of hospitality facilities, with increasing competition. The generally accepted trend of healthy life can be the key to the success of the tourism market. In terms of tourism and inflow of foreign tourists, organic food production has singled out (HrabovskiTomić, 2010). Organic food can be seen as a significant comparative advantage and a form of differentiation of tourist offer (Đenadić, 2010) where Vojvodina can have a significant place and benefit. Vojvodina has great potential for organic food production, as Zubović and Domazet (2007) suggest it has unpolluted land, climatic advantages and numerous agricultural producers whose products can be found in the offer of various hospitality facilities for the production and serve of food and beverages.

\footnotetext{
Department of Geography, Tourism and Hotel Management, Faculty of Sciences, University of Novi Sad, Serbia College of Professional Studies for Management and Bussines Communication, Sremski Karlovci, Serbia

* Corresponding author: jecadevic@gmail.com
} 
For a modern consumer, organic food association for high-quality food, sustainable agriculture development, preservation of ecosystems, maintenance and increase of soil fertility as well as reduction of soil contamination, with the maximum use of renewable energy sources, maintenance of genetic diversity of agro and ecosystems (Đoković et al. 2013).

Tourists during their stay in a particular tourist destination must satisfy their physiological needs for food, which are increasingly focused on food of organic origin. Food or experience of eating is one of the important factors that affect the perception of the destination by tourists. $\mathrm{Hu}$ and Ritchie (Hu, Ritchie, 1993) emphasize that food is the fourth factor contributing to the perception of the attractiveness of the destination after climatic conditions, accommodation and landscape, highlighting the importance of improving the gastronomic offer in tourism. Tourist activation of a certain area contributes to the agriculture, food industry and hospitality industry, making food an important resource for tourism (Henderson, 2004; Quan, Wang, 2004), which causes more than onethird of the total tourism consumption of global tourism (Meler, Cerovic 2003).

Research on the relationship between food and tourism has been performed from different perspectives (Horng, Tsai, 2010; Su, Horng, 2012), many tourist destinations, noting the significance of tourism development, improved the promotion of their local products (Du Rand, Heath, 2003, Henderson, 2004; , Crotts, 2005; Du Rand, Heath, 2006; Hashimoto, Telfer, 2006; Okumus et al., 2007; McKercher et al., 2008).

The subject of the paper is the supply of organic food, that is, dishes in hospitality facilities for the provision of food and beverages, but which are part of the accommodation facilities in the territory of Novi Sad. The task of the paper is to answer the following research questions:

1. Do consumers of products and services in hospitality establishments search for foods prepared from products of organic origin?

2. Do the restaurant facilities or cuisines use products of organic origin?

3. Do hospitality workers easily come to organic products?

4. How do hospitality workers buy food from bio-farms?

5. Do restaurants offer organic dishes?

6. Do restaurants have in their offer a bio-corner in a breakfast offer?

7. Do restaurants offer bio-menus in their offer?

The aim of the paper is to examine the level of the organic food supply in the hospitality industry, but also the availability of such products in line with the demand.

\section{LITERATURE REVIEW}

In the 1990s, the number of organic food producers increased significantly. At the same time, there is an increasing demand for such products. Significant implications of local food consumption on tourist destinations are noticeable and there is an increasing interest in exploring the same area (Mak et al., 2012). When it comes to consumer motivations for this type of food in restaurants, the most dominant are: expected health 
benefits, attractive and modern foods, a search for sensory more acceptable foods (Roitner-Schobesberger et al., 2008). It is evident that the organic food market is developing relatively rapidly, but its participation in the total supply is still low although the production and sale of organic food is regulated by appropriate regulations related to production (agricultural products, forest fruits and medicinal herbs and food products obtained by their processing), labeling, storing, manipulating, transporting and certifying (Savić et al., 2006).

It is believed that organic food production is potentially one of the most profitable businesses in the world (Curić, Ceranic, 2011). Trade in organic products has been steadily growing. Consumer demands quality and health-safe food of plant and animal origin produced in an untapped natural environment are increasingly pronounced (Milić et al., 2010). Some studies have shown that food produced by an organic production method is nutritionally better and contains more antioxidants than foods that are not produced in this way (Paddock, 2007). Bearing in mind the effects of organic food on human health, positive consumer reactions and global food trends, there is an increasing number of restaurants in the world that have at least some food or drink made from organic foodstuffs in their offer. There are hospitality facilities in the world that have gone a step further and the whole offer is based on organic food. Organic food is one of the three leading trends when it comes to menus in restaurants (Stensson, 2006). According to a study relating to the reasons why restaurants serve organic foods, Pulston et al. (Poulston et al., 2011) suggest two main reasons: profit and care for health and environment.

Organic food production is a strictly regulated area (Tananeva, 2010), in order to form organic agricultural production in one area, it must meet precisely defined conditions (Đoković et al., 2013). The potential for organic agriculture has until recently been underutilized and farmers are not sufficiently motivated for this type of production (Curić, Ceranic, 2011). This diet involves the diet of certain classes of consumers, primarily those with high purchasing power and those who are occupied with the fear of using harmful foods and the development of certain diseases (Cvetković et al., 2016). With the focus on tourism development, the state and businesses must be required to influence trade flows with organic products in order to achieve mutual benefits (Milić et al., 2010).

Organic agriculture contributes to increasing competitiveness, as well as the rural development of the country through the preservation of the environment and supplying consumers with quality (organic) products. With this kind of agriculture, all stakeholders are satisfied, as it helps the region to preserve its natural resources, consumers get health-safe food, and producers higher profit (Tomić et al., 2010).

Authors emphasize that in order to acquire a culture of consuming organic foods, as well as habits, young people must be educated to use to the fact that organic food is the source of human health and the preservation of the environment. Therefore, in Vojvodina, awareness-raising action on the importance of health-safe food (especially fresh fruits and vegetables) should be initiated by educational institutions (Tomić et al., 2010). What is most important is to organize education within hospitality facilities in order to provide adequate services to guests oriented to organic nutrition. The concept of "Slow 
Food" coincides with the core of the concept of organically produced food that is produced with patience, great investments in its quality, which contributes to a better and healthier life of people, while at the same time taking care of the environment and local development of the region.

The domestic market for organic products is still small and underdeveloped. All parts of the organic production chain are present, but they are not connected, so the sector is not well organized, which leads to lack of coordination and cooperation between various projects, activities and stakeholders as stated by Paunković et al. (2013). The development of the domestic market is slowed down due to the lack of organization of production and distribution and poor promotion in the media (Paunković et al., 2013). The more significant inclusion of organically grown food into Vojvodina's tourist offer, along with food diversity, can significantly contribute to its better positioning and increasing competitiveness (Đenadić, 2010).

\section{METHODOLOGY}

For the purposes of the paper, the research was carried out by gathering data through interviews of employees in the hotel industry, that is, the restaurants within them, as an adequate method for obtaining this type of data. The research was conducted in 12 hotel restaurants on the territory of the city of Novi Sad. The interviews were conducted with people who could provide reliable information, such as restaurant managers, managers, kitchen chefs, and shift managers. The survey included a total of seven questions related to the production and consumption of organic food. All responses were, after interviewing, converted into clear claims whose structure was statistically processed and graphically presented in the paper along with the discussion. The research questions related to the following elements that are crucial for this type of study:

1. demand for organic food;

2. use of organic food;

3. availability of organic food;

4. purchasing organic food;

5. inclusion of organic food in the total supply;

6. possession of bio-corner for breakfast and

7. bio-menu offer.

\section{RESULTS AND DISCUSSION}

In order to start from the analysis of the offer, the demand for organic food within the hospitality facilities should be investigated (Chart 1). Through interviews with employees, it became clear that guests look for food based on organic products offered in $74.97 \%$ of facilities and that such requests are becoming more and more frequent every day. 


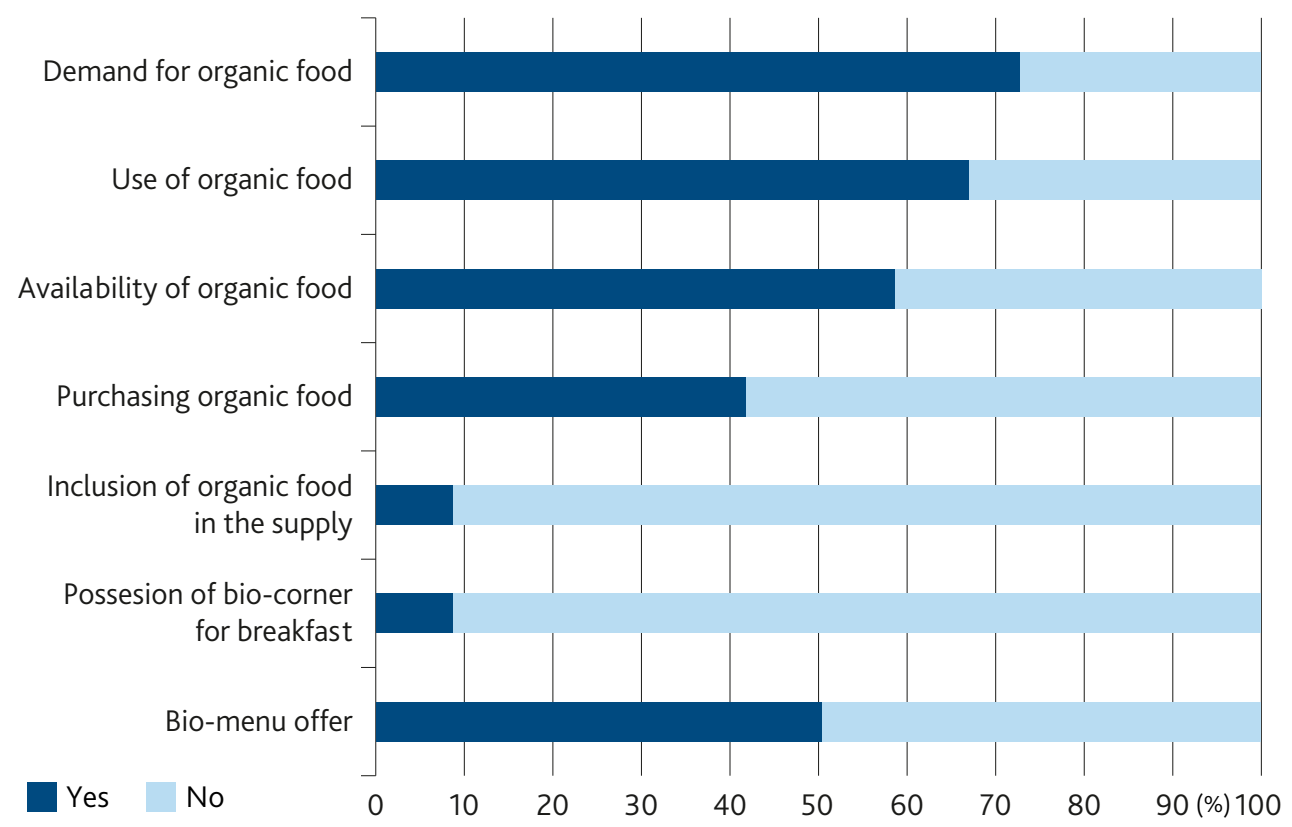

Figure 1. Relationship between demand and supply of organic food

The significance of the health quality of foods that are put into the human organism has determined the trend of food production grown organically. The more significant inclusion of organically grown foods in the hotel-tourist offer of Novi Sad hotels has not been recorded, and this should be changed because it would significantly contribute to better positioning and increase of competitiveness.

Most hospitality facilities when needed purchase food with organic production label (66.64\%), declaring that it is difficult to obtain as confirmed in $58.31 \%$ of facilities. Hotels do not purchase directly organic food from farms that produce it, that is, grows it because its selling value is unfavourable to all actors in the chain, and ultimately to the guest. The reason for this is the fact that the domestic market is small and undeveloped, and therefore products are hardly accessible and facilities are often forced to buy products from imports.

Unfortunately, only one hotel restaurant in its offer has $1 / 3$ organic food and a biocorner for breakfast. This confirms that hospitality offer should be given a new dimension, or expand the offer of foods prepared from foodstuffs that guests perceive as beneficial to their organism (healthy), as stated by some authors (Gagić et al., 2011; Gagić et al., 2014).

Hospitality facilities prepare bio-menu only by orders in the half of the interviewed restaurants, only when the demand exists, which in this case provides them with an easy and good profit with difficulties in justifying the price because such foods have high purchasing value. 


\section{CONCLUSION}

Environment and tourism constitute an indivisible whole, but their connection is increasingly reflected in specific nutritional requirements such as the use of organically produced food. With the application of domestic and foreign literature, and with the help of personal insight into the current state and business of Novi Sad hotel restaurants, the following conclusions have been reached that guests in $75 \%$ of the examined objects are looking for a food based on organic products, and such requests tend to grow. The more significant inclusion of organic food in the hotel-tourist offer of Novi Sad hotels was not recorded, as $65 \%$ of them only purchase such products as needed. The potential for organic agriculture is underutilized because hospitality facilities have difficulty in procuring such foods, saying that it is hardly accessible and that purchases directly from agricultural holdings are often not practical.

Analyzing the regular offer of hospitality facilities, there has been a worrying fact that only one hotel has $1 / 3$ organic food (which should be thoroughly explored) and a bio-corner for breakfast. Half of the surveyed hotels are preparing menus only by order. This confirms that the hospitality offer needs to be given a new dimension, that is, to expand it making the market differentiation, better positioning and increasing the competitiveness of Novi Sad hotels, thereby supporting the economic development of the region.

\section{ACKNOWLEDGMENTS}

The paper presents the results of the research on the project 142-451-2669/2017 financed by the Provincial Secretariat for Higher Education and Scientific Research.

\section{LITERATURE}

Cvetković, B., Kalenjuk, B., Tešanović, D. and Babić, M. (2016). Gastronomic needs of modern tourists as a problem of tourism market. Researches Review DGTH, 45/2, 117-131.

Curić, J. and Ceranić, S. (2011). Chain of value of organic food in Serbia. Researches Review Institute PKB Agroekonomik, 17/3-4, 185-191.

Đenadić, M. (2010). Healthy food as a factor of Serbia's tourism competitions. Economics of Agriculture, 57/4, 681-690.

Đoković, G., Vuković, A. and Rončević, D. (2013). Presence of organic food products in world trade flows. Ecologija, 20/72, 719-724.

Gagić S., Psodorov, D., and Ostojić, G. (2011). Principles of innovative gastronomic offer. Researches Review DGTH, 40, 188-197.

Gagić, S., Tešanović, D. and Kalenjuk, B. (2014). Improvement of business performance in restaurants using innovation strategies. Turističko poslovanje, 14, 91-99.

Hashimoto, A. and Telfer, D. J. (2006). Selling Canadian culinary tourism: branding the global and the regional product. Tourism Geographies, 8/1, 31-55. 
Henderson, J. C. (2004). Food as a tourism resource: A view from Singapore. Tourism Recreation Research, 29/3, 69-74.

Horng, J. S. and Tsai, C. T. S. (2010). Government websites for promoting East Asian culinary tourism: a cross-national analysis. Tourism Management, 31, 74-85.

Hrabovski-Tomić, E. (2010). Agri business and food processing industry in the function of tourism industry's development. Economics of agriculture, 57/3, 487-497.

Hu, Y. and Ritchie, J. B. (1993). Measuring destination attractiveness: A contextual approach. Journal of Travel Research, 32/2, 25-34.

Kivela, J. and Crotts, J. C. (2005). Gastronomy tourism: a meaningful travel market segment. Journal of Culinary Science \& Technology, 4/2-3, 39-55.

Mak, A. H., Lumbers, M., Eves, A. and Chang, R. C. (2012). Factors influencing tourist food consumption. International Journal of Hospitality Management, 31/3, 928-936.

McKercher, B., Okumus, F. and Okumus, B. (2008). Food tourism as a viable market segment: it's all how you cook the numbers. Journal of Travel \& Tourism Marketing, 25/2, 137-148.

Meler, M. and Cerovic, Z. (2003). Food marketing in the function of tourist product development. British Food Journal, 105/3, 175-192.

Milić, D., Popović, N. and Lukač-Bulatović, M. (2010). Economic aspects of the development of organic production. Modern agriculture, 59/3-4, 242-249.

Okumus, B., Okumus, F. and McKercher, B. (2007). Incorporating local and international cuisines in the marketing of tourism destinations: the cases of Hong Kong and Turkey. Tourism Management, 28/1, 253-261.

Paddock, C. (2007). Organic Food Is More Nutritious Say EU Researchers. Downloaded from http://www.medicalnewstoday.com/articles/86972. php 2012 Aug 12.

Paunković, D., Cvetković, A., Žikić, S. and Marić, M. (2013). Analysis and perspectives of the organic food market in Serbia. Ecologica, 20/72, 622-625.

Poulston, J., Yau, A. and Yiu, K. (2011). Profit or principles: Why do restaurants serve organic food. International Journal of Hospitality Management, 30/1, 184-191.

Quan, S. and Wang, N. (2004). Towards a structural model of the tourist experience: an illustration from food experiences in tourism. Tourism Management, 25/3, 297-305.

Roitner-Schobesberger, B., Darnhofer, I., Somsook, S. and Vogl, C.R. (2008). Consumer perceptions of organic foods in Bangkok, Thailand. Food Policy, 33/2, 112-121.

Savić, M., Mijajlović, N. and Katić, B. (2006). Legal outline for production and market of organic food in EU and SCG. Economics of agriculture, 53/3, 719-725.

Stensson, A. (2006). New survey reveals what's hot on restaurant menus. Downloaded from http://www.nationalrestaurantassociation. com/pressroom/print/index.cfm

$\mathrm{Su}, \mathrm{C}$. S. and Horng, J. S. (2012). Visions for Global Tourism Industry - Creating and Sustaining Competitive Strategies. Rijeka: InTech.

Thananeva, Z. (2010). Market status of organic products in the countries of the European Union. Marketing, 41/4, 256-260.

Tomić, G., Đurica, M. and Bugar, D. (2010). Management of promotion of organic products and the role of educational institutions in Serbia. Economics of agriculture, 57/4, 671-680. Zubović, J. and Domazet, I. (2007): World trend analysis as a tool for development of organic food market in Serbia. Economics of agriculture, 54/4, 521-532. 